\title{
The Adaptation of Industrial Heritage in the Context of Existing Urban Structures
}

\section{Daniel Struhařík}

Tutor: prof. Ing. arch. Vladimír Šlapeta, DrSc., Ústav teorie architektury, Fakulta architektury, Vysoké učení technické v Brně E-mail address: xastruharik@stud.fa.vutbr.cz

\begin{abstract}
Two industrial sites are compared on the basis of a collective case study - a former textile factory complex belonging to Vlněna in Brno which has been demolished, together with the Löwenbrau brewery, which has been converted into a viable site with apartments, offices and a gallery (thanks to the reconversion and completion of new contemporary layers).

The fundamental difference was found to be a result of the respective public sector's differing approaches, especially in the sphere of spatial planning. Due to the long-term strategy, identification of qualities and potential based on discussions with developers and the further involvement of other participants, Zurich city is about to revive its industrial quarters whilst also preserving important traces of the past. The example of Brno is different. The spatial "zoning" method causes a specific development without maintaining any existing spatial qualities. Another reason is the attitude of the National Heritage Institute, which does not take the importance of the Vlněna complex into consideration in its decisions altogether with its reference to the former development of Brno city as a part of the local industrial heritage.
\end{abstract}

KEYWORDS: Löwenbräu; reconversion of the brewery; Vlněna; textile industry; spatial planning; industrial heritage; heritage protection

ABSTRAKT: Na základě kolektivní případové studie je provedena komparace dvou průmyslových areálů - brněnského textilního komplexu Vlněna, jenž byl zdemolo- 
ván, a curyšského pivovaru Löwenbrau, který byl díky konverzi a doplnění soudobé vrstvy přestavěn na životaschopný celek s byty, kancelářemi a výstavní galerií.

Zásadní rozdíl byl nalezen ve zcela odlišném př́istupu veřejného sektoru, a to zejména v principu územního plánování. Díky dlouhodobé strategii, určení kvalit a potenciálu na základě diskuze s developery a participaci ostatních subjektů dochází v Curychu k oživení industriální čtvrtě při zachování stop minulosti. Brněnský příklad je opačný. Způsob plánování, jenž je závislý na zónování, je př́ičinou rozvoje města, při němž nejsou zachovávány stávající kvality. Dalším důvodem je postoj Národního památkového ústavu. Ve svých rozhodnutích nebere v potaz komplex areálu jako celek, jenž je odkazem rozvoje moravské metropole a zároveň součástí průmyslového dědictví.

KLÍČOVÁ SLOVA: Löwenbräu; přestavba pivovaru; Vlněna; textilní průmysl; územní plánování; průmyslové dědictví; ochrana dědictví

\section{Introduction}

The topic of accessing the industrial heritage of the 19th and 20th centuries is not just a trending topic in the Czech Republic, due to the large-scale production complexes near the centres of big cities [1]. Thanks to their positions towards historical centres, these premises are very lucrative for developers. Another quality of these industrial sites is also their architectural value, which is not always possible to highlight and maintain in local conditions [2]. An example of this is the recent demolition of the Vlněna textile factory complex in Brno [3]. The city's memory of an important historical era has been permanently removed. This loss of identity is bolstered by gradually implemented new development proposals being gradually implemented which, following demolition, creates the new urbanism of "super districts" in the spirit of the tabula rasa concept. Although these industrial objects have lost their importance over time, their quality lays particularly in clearly defined urban structures.

Based on the existence of project "Swiss-Czech inspiration" [4], a study trip to Switzerland took place in 2015. Together with students from the ETH (Swiss Federal Institute of Technology) in Zurich, it was possible to complete the required observations, interviews and local research of the selected objects. This event was the starting point for further comparison between Czech and Swiss environments. The most striking difference was visible in the Zurich-West district (an area in which the city's industrial history was established), which is currently under development. The combination of industrial architecture together with the contemporary layers encourage us to think about the area as a place with a unique atmosphere. 
The relevance of this topic (dealing with traces of the industrial era) is supported by the abundant activities taking place in the fields of professional and public education. The key point is to analyse why preserving historically valuable remains of industrial heritage is not always successful. Through the collective case study of the Vlněna complex in Brno and the Löwenbräu brewery in Zurich, two industrial areas with a completely different approach and fate are compared. The Vlněna complex in Brno gradually becomes an example of the mindless development of a modern office park, while the Löwenbräu brewery in Zurich, thanks to the specific development of new architecture together with the preservation of existing industrial buildings, is an example of a viable area with the potential to support the existing genius loci whilst reasonably rationalizing the density of the city.

\section{Industrial heritage protection tools}

The Industrial Revolution meant massive urbanization for many cities. Gradually, this so-called production power began to shift from the "primer" to the "secunder". A city seemed to be an ideal example of an environment for the concentration of resources and production power. As a result, people started to move from the villages to the cities. This was also due to degraded working and living conditions, together with the construction of new factories, which became symbols of a "new society". The beginning of the 1970s implied a gradual restructuring of the economy and the emergence of a post-industrial society, resulting in the relocation or disappearance of industrial production [5]. Production complexes began to disappear with greater frequency.

The TICCIH Commission (The International Committee for the Conservation of the Industrial Heritage) was set up as a response to the increasing destruction of industrial heritage sites. The TICCIH Commission has developed forms, methods and principles of industrial heritage protection. One of the commission's outputs was the TICCIH Industrial Heritage List [6]. It defines the concept of "industrial heritage" itself, which at the time did not involve only architectonically isolated objects, but also the entire areas - complexes. Industrial heritage not only captures the historical moments of human society, but has also been a part of cultural legacy for past generations.

\section{The textile factory Stiassny and Neumark (VIněna) as a broken link to the past}

The Vlnena complex in Brno recently underwent demolition works and is now in the phase of rapid development of new structures. The industrial complex of the former textile factory is basically being replaced by a cluster of administrative buildings. 


\subsection{Location within the city}

The area is situated in the south-eastern part of the city, directly linked to the city centre, yet divided by the existing main railway station. There is a development site called "Jižní centrum" in the immediate vicinity of the Vlněna complex, wherein a dense development of new residential and office buildings has been expected recently [7]. While maintaining some historic industrial objects and the administrative building, an extensive shopping mall has been built on the site of former "Vaňkovka" machine factory. These are due to the activities of the civic association and public participation. The newly emerged shopping mall is also a part of "Jižní centrum” area.

\subsection{History}

The beginning of Brno's industrialization dates back to the mid-18th century, when this "business" was supported mainly by the initiative of the Moravian Manufactory Office and the Moravian Bank [8]. The former textile factory of Vlněna emerged in these premises mainly thanks to Leopold Köffiller. New factories were developed in the area because of a general increase in sales in the whole sector and people started to nickname Brno the "Moravian Manchester" [9]. The connection of the city to the railway network can be also considered as a significant event [10] for those times. At the end of the 19th century, some of the factories were bought by Paul Neumark and Josef Stiassny. Partial reconstruction of the factory complex was proposed by prominent local architect Ernst Wieser [11]. The whole complex was called "Vlněna, n. p." in 1945 while being nationalized [12]. The importance of engineering and of the Brno industry, in general, was increased during this time, mainly as a result of progressive mechanization. However, the operations were completely terminated and the buildings included in the complex were sold during the 1990s.

\subsection{Characteristics of the area before demolition}

The whole Vlněna complex consisted of several production buildings with a different construction system, altogether creating a significant density within the area. Buildings strictly adhere to the street line. The Neo Renaissance Bochner Palace is situated on Prrízova Street. The cluster of objects is clearly defined and enclosed while creating a variety of public spaces with each different character. The buildings were made of bricks and reinforced concrete in combination with cast iron beams. From a structural point of view, it appeared that some of the buildings were half-destroyed due to ageing [13]. 


\subsection{Transformation process}

From the 1990s, the original textile production gradually disappeared. Despite the unfortunate state of the complex, this space became an ideal place for small businessmen and creative artists, who used the spaces as flats and studios. There was also the Gallery of Mr. Štovíček, which presented the work of local artists. The reason for this concentration of creative individuals was the industrial space itself together with its specific atmosphere while maintaining low rent [14]. The Vlněna complex became a place where one could organize large scale cultural events and performances. It is worth mentioning that the "Potenciál" music festival or "Die_Sein" performance by progressive local experimental theatre platform D’Epog took place there in the past [15]. The whole complex was demolished in 2016. Only building No. 1 on Přízova Street remained - namely the Neo Renaissance Bochner Palace, the administrative building of the former company built in 1867 [16].

\subsection{Developer}

Now the former Vlněna complex is owned by CTP Property XVII, spol. s r. o. who also acts as a developer of the complex these days. The company is owned by the Dutch developer group CTP, which is one of the "greatest players in the field of industrial development" in Central Europe. This company mainly focuses on development, construction works, and the renting and management of logistic complexes. The Spielberk Office Center and the Ponávka Business Park are worth mentioning as examples of their activities [17]. Newly emerged buildings seek the BREEAM certificate, which reduces the impact of construction on the surrounding environment. According to the Regional Director's statement, the developer is forced to quickly proceed to the construction phases because of the demands. In his view, there is huge interest in constructing mainly new buildings there [18].

\subsection{The architectural concept of the new development}

In general, there was basically no information available about the proposal of the architect Václav Hlaváček and his studio. The architect himself has not yet published this project on his website [19]. However, the proposal consists of a very similar complex of buildings to the administrative complex on the river Svratka - Spielberk Office Centre. The new proposal consists of several commercial buildings that adhere to the street line of Dornych and Př́zova Streets. The mass of the complex "opens up" and creates a solitaire office building in the corner of the complex on Př́zova Street. There is a park along the buildings which separates the blocks of offices so that one can find a lot of greenery and a pond. The project counts on the preservation of Bochner's palace. 

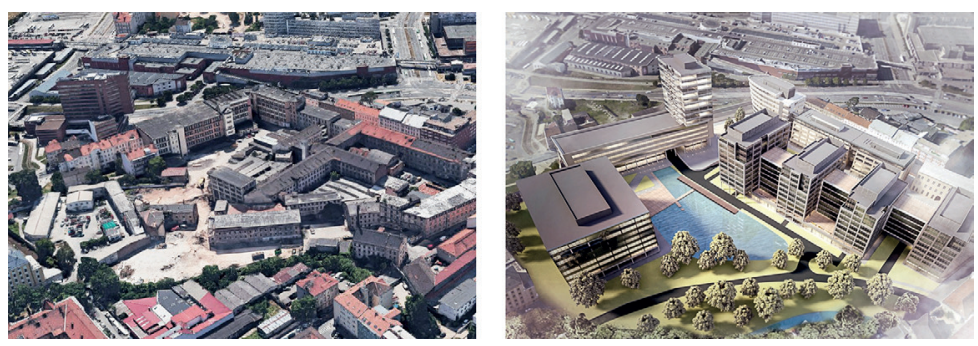

Fig. 1, 2. Comparison of the complex before planned demolition with the final proposal. Photo: Google, Studio Acht.

\subsection{Public sector}

According to the National Heritage Institute (NPU) in 1999, the site is not a cultural monument. Subsequently, the NPU, together with the City of Brno, stated that complete demolition is the final solution for the former Vlněna complex. They decided so without any further comments. Knowing this, the NPU submitted a proposal about preserving the Bochner Palace to the Ministry of Culture. This proposal was rejected due to the existence of long-term demolition plans [20].

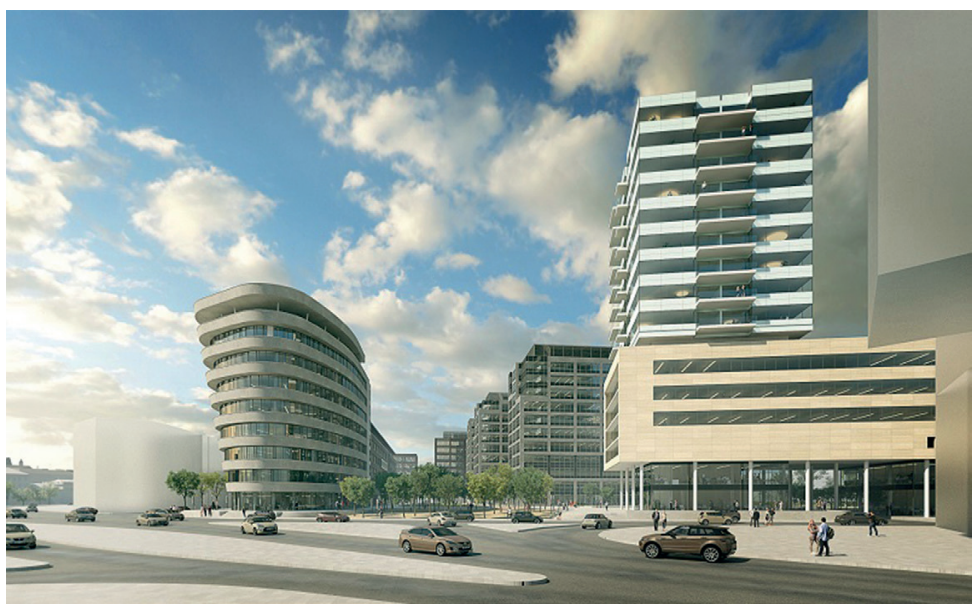

Fig. 3. Perspective - pedestrian point of view. Photo: Studio Acht. .

\section{Löwenbräu - a lively urban block}

The Löwenbräu complex, located in Zurich, Switzerland, is an example of a lively urban block in the context of redevelopment, extension and the partial replacement of 
existing buildings by new layers. There is an artistic centre, a residential tower and office building. The industrial character of this place is complemented by contemporary architecture. This is an example of a location with a specific quality that is also commercially successful.

\subsection{Location within the city}

The complex is situated near to the Zurich city centre in the Zurich-West district. A well-connected railway infrastructure predestined means the location was predestined to be an area of industry and production.

The production complex itself was situated near the river. It was divided by a partially functioning Swissmill, through which grain is progressed. An adjacent viaduct was connected to the complex from the southwest direction. Thanks to the proposal of the EM2N architectural studio, the viaduct is now integrated into the city structure and supports its life. The whole place has become a commercial promenade filled with boutiques and design shops, mainly because of the sensitive transformations and additions proposed by architects.

\subsection{History}

The complex dates back to 1898, when Zurich banker Kugler Borsinger founded the Wald-Feldbach company and started to operate a new brewery in the area. There was a slight decrease in production during the First World War. In addition to this, the brewery had to be restructured, and a small company by the name of Löwenbrau bought it and renamed it Löwenbräu Zurich AG. The end of the Second World War resulted in increased production [21]. The meaning and effects of the modern era resulted in the total disappearance of the original production, while the complex has been protected as national heritage. This fact led to the creation of a gallery, which still acts as a catalyst for further expansions of the whole area.

\subsection{Characteristics}

The complex consisted of a silo, a chimney and several production objects which were built during different points of the development process. A compact site with one significant "courtyard" was created. The buildings were made of bricks and concrete, and completed with cast iron columns. The façade was made of a tectonic composite. "Columns" on the façade were complemented with a facing made of bricks of differing colours. 


\subsection{Transformation process}

The transformation of the complex is related to the transformation of the whole $\mathrm{Zu}$ rich-West district. The neighbourhood with previously empty industrial buildings has turned into an area supported by a unique character, mainly because the empty production objects were perceived as a new opportunity for the area. At this point, it is worth mentioning Toni Areal, which was designed by EM2N studio. Toni Areal was the site of a dairy plant, which was converted into a generous art's school with other cultural facilities or Frau Gerolds Garten - a place bringing together urban gardening, restaurants and pop-up style shops.

Conversion is also the case of the former Löwenbrau brewery site. The entire transformation of the complex was initiated by the creation of the gallery, situated in the southern part of the complex. This trigger mechanism led to the reconversion of the entire area, which was considered as the best possible solution, even for a private investor. The process of transformation was started by an architectural competition, which was won by Anette Gigon and Mike Guyer together with the WW Architekten architectural studio.

\subsection{Developer}

The developer of Löwenbräu is a Swiss company called PSP Swiss Property Ltd, one of the "greatest players in the estate fields" in Switzerland. The company is mainly active in the residential and office properties market. The company is oriented toward longhorizon investments, while its business plan is oriented toward the construction or complete renovation of existing buildings. The company's interest also lays in reducing pollution, as well as energy, water and $\mathrm{CO} 2$ consumption [22].

\subsection{The architectural concept of the new development}

The main theme of the project was the idea of city densification. The development of a dense structure supports the idea of short walking distances, while ensuring the concept's sustainability. Preserving the original historical buildings was an important aim, together with maintaining the identity of such an industrial area.

Vertical dominants - two towers were designed to support the actual significant horizontal mass of former factories. The central high-rise residential building with apartments and the new east office building also serve as offices The last element to be added was the construction of the new west building on the top of existing gallery. The façade is penetrated by a grid of clearly defined squared windows. Red and black 
colour was used because of the continual transformation of surfaces adjacent to the original brickwork of the former brewery. To intensify the experience of the building, a glossy glazed waved pattern was used as finishing layer [23].
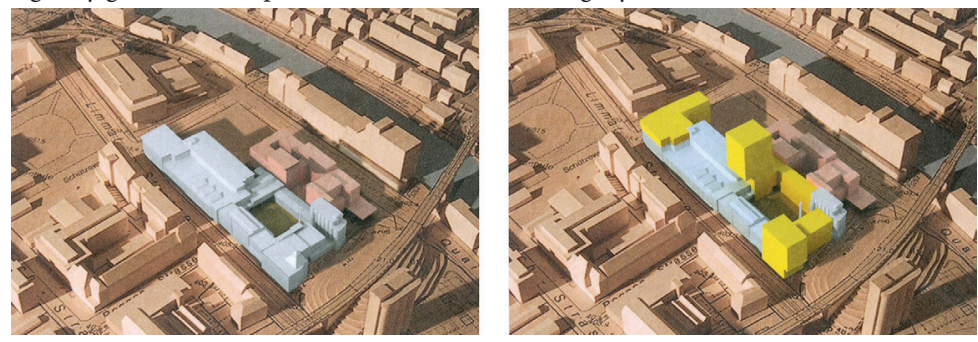

Fig. 4. Comparison of existing buildings in Löwenbräu complex with the proposal. Photo: Gigon Guyer Architekten.

\subsection{Public sector}

Due to the long-term strategy of the city within the Zurich-West district, the whole site is gradually developing.

Spatial planning of Zurich went through a significant change. From the directionally determined urban zoning (typical for the 1990s), the city embraced this so-called conceptual urbanism (Konzeptioneller Städtebau), thanks to the Office for Urban Planning (Amt für Städtebau, Hochbaudepartement Stadt Zürich). This progressive approach does not take into account the definition of boundaries or regulations, but depends on interpretations, visualizations, sketches and models. It is based on the assumption that the city cannot be fully planned and controlled, so the concept works within the city according to the present. The process of spatial planning is a workshop, a laboratory where all of the important partners are involved. As a result, a "test" plan in the workshop process is being developed.

One of the key projects of this office is Zurich-West, wherein a long-term strategy for this territory has been established. Three architectural studios were invited and have proposed different solutions for the development of this industrial district. The final decision about the complex's basic principles was made after this architectural competition, together with the realization of a "workshop" for invited architectural studios, external partners and property owners. Based on this, a declaration of strategic intentions and an agreement between the City of Zurich and property owners was established. Due to clear formulations of spatial planning principles and, also due to the opening of the site to the public, the whole neighbourhood has been further developed day by day [24]. 


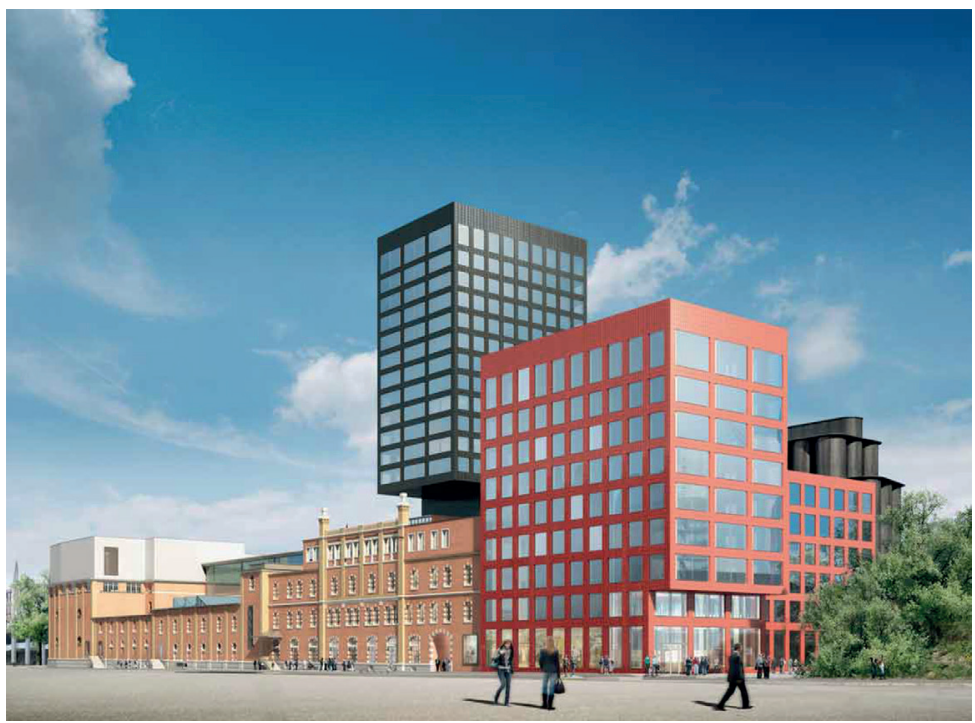

Fig. 5. Perspective - pedestrian point of view. Photo: Gigon Guyer Architekten.

\section{Outcome}

The starting point for comparing the development of these two industrial complexes was the relevance of each selected case. Both cities have a comparable population and both can be defined as post-industrial. As a result, the gradual development of human society led to the existence of numerous brownfields. Another important factor is the relationship to the city centre, walking distances and railway connectivity. Despite the different economic development of each country, it is important to trace the destinies of both complexes.

Both cities were compared according to their approach, developer's interests and architectural concept. All of this was set against their wider geographical and historical contexts.

The main difference between the cities lies in their approach to spatial planning. A long-term strategy is taking place in Zurich involving "all players" in the process of transforming the site, especially throughout the Zurich-West district. Speaking of the City of Brno, the spatial plan only defines the area's architectural programme, whilst the publication "Brno brownfields", which was published recently is rather an example of how to offer lucrative lands within the city [25] for sale. The monument protection of both sites is different as well. Yet, the activation process of each area is worth exploring. Both sites were independent from the activities of developers. Both of them were "centres of culture" in the past. 


\begin{tabular}{|c|c|c|}
\hline Observed phenomena & Vlněna (Brno, Czech Republic) & $\begin{array}{l}\text { Löwenbräu (Zurich, } \\
\text { Switzerland) }\end{array}$ \\
\hline \multicolumn{3}{|l|}{ Complex within the city } \\
\hline City population & $380,000[27]$ & $403,000[28]$ \\
\hline $\begin{array}{l}\text { Past (19th century), prevailing } \\
\text { economic activity }\end{array}$ & Industry & $\begin{array}{l}\text { Industry, the importance of } \\
\text { bank sector }\end{array}$ \\
\hline $\begin{array}{l}\text { Present ( } 21 \text { st century), prevailing } \\
\text { economic activity }\end{array}$ & Post-industrial society & Post-industrial society \\
\hline $\begin{array}{l}\text { Production locations in the city, } \\
\text { significant brownfields }\end{array}$ & $\begin{array}{l}\text { Zbrojovka, Jižní centrum, Vlněna, } \\
\text { Mosilana }\end{array}$ & $\begin{array}{l}\text { Hürlimann site, Zurich- } \\
\text {-West, Letzi District }\end{array}$ \\
\hline
\end{tabular}

\begin{tabular}{|c|c|c|}
\hline \multicolumn{3}{|c|}{ Production complex - before recent interventions } \\
\hline Purpose of the complex & Production of woollen fabrics & Beer brewing \\
\hline $\begin{array}{l}\text { Importance of the complex within } \\
\text { the city / region }\end{array}$ & $\begin{array}{l}\text { Foreign export, development of the } \\
\text { city via export }\end{array}$ & Local importance \\
\hline Beginning of the production & 1791 & 1898 \\
\hline Site size (ha) & 5 & 2 \\
\hline Distance from the city centre & 0 & 2 \\
\hline Connection with the railway & $\begin{array}{l}\text { Direct connectivity, proximity to the } \\
\text { main railway station }\end{array}$ & $\begin{array}{l}\text { Direct connectivity, pro- } \\
\text { ximity to the main railway } \\
\text { station }\end{array}$ \\
\hline Heritage protection & Without protection & Protected \\
\hline Concept of the city & No concept & Long-term strategy \\
\hline $\begin{array}{l}\text { Activities of the public and the } \\
\text { function of the complex before } \\
\text { the reconstruction / new building }\end{array}$ & $\begin{array}{l}\text { Used for business activities, as } \\
\text { apartments, studios, exhibition spa- } \\
\text { ces, for cultural events }\end{array}$ & $\begin{array}{l}\text { Gallery of international } \\
\text { importance }\end{array}$ \\
\hline \multicolumn{3}{|l|}{ Production complex - present } \\
\hline Owner & Private company & Private company \\
\hline $\begin{array}{l}\text { Selecting the architect, beginning } \\
\text { of planning }\end{array}$ & $\begin{array}{l}\text { Direct input, without competition, } \\
\text { based on previous collaboration }\end{array}$ & $\begin{array}{l}\text { Architectural competition, } \\
2003\end{array}$ \\
\hline Project, realization & $2006-2020$ & $2004-2013 / 2014$ \\
\hline $\begin{array}{l}\text { Methods of using the existing } \\
\text { complex }\end{array}$ & $\begin{array}{l}\text { The concept of tabula rasa - almost } \\
\text { complete demolition, without any } \\
\text { connection to the original structure }\end{array}$ & $\begin{array}{l}\text { Connections to existing } \\
\text { complex, the addition of } \\
\text { new architecture, partial } \\
\text { demolition }\end{array}$ \\
\hline New complex features & $\begin{array}{l}\text { Office spaces with commercial } \\
\text { parterre }\end{array}$ & $\begin{array}{l}\text { Extended exhibition areas, } \\
\text { living, work }\end{array}$ \\
\hline
\end{tabular}

Tab. 1. Evaluation of the collective case study Vlněna, Löwenbräu. 
Based on the Vlněna complex case study, it is clear that nowadays approaches to preservation of industrial monuments in the Czech Republic are rather non-conceptual, although there are also good examples [2][3]. On the other hand, in Switzerland, it is intended to transform the efforts of preserving architectural qualities of "historical trails" into valuable marketing strategies [26].

\section{Discussion and conclusion}

This paper focuses mainly on the collective case study of two industrial sites. The former textile factory Vlněna was almost completely demolished, despite its former transnational importance in the past. According to future plans, a development of "sterile" office buildings will take place in the coming years on the existing site. The former, locally significant Zurich brewery Löwenbräu has been preserved as part of an effort to preserve the historical trails together with the general implementation of city's densification principles, whilst all participants of the development process were working together hand in hand. The aim of this paper was to analyse the causes of the different development of two industrial sites.

Despite the fact that the former Vlnena complex proceeded the same investigation process as the Löwenbrau complex, nobody has studied either of the following: The reasons for the complete demolition of the Vlněna complex as an important industrial monument worth heritage preservation, and the causes of the complete reconversion of the Löwenbrau industrial complex and the addition of new structure.

The fundamental difference lies in the approach of each city's administration to the analysis of each complex and especially of the whole area itself. In Zurich, there was a long-term strategy planned for the whole area, thanks to the existence of the conceptual urbanistic-architectural competition, as well as further discussions with potential developers and property owners. Based on those discussions and opened platforms, a "test" plan was made for the area through "clear visions".

In Brno, its approach works with the site without involving any additional contexts. The area cannot operate with any unified concept. It is also not possible to involve important "players" in this "game" as the property owners and other developers are not invited to the "discussion".

In-depth analysis of planning approaches in Zurich in comparison with planning approaches in Central Europe could be a very interesting source of inspiration for further development and spatial planning in local areas. Yet methods of spatial planning in the Czech Republic still depend on spatial "zoning", which act as an obstacle 
which does not derive from the qualities of space and thus does not lead to a "healthy" development of existing areas.

The Vlněna complex in Brno became a local cultural phenomenon of a specific kind based in a significant environment. The same thing intended for the "Káznice" project (creation of a cultural creative centre) seems like a contradiction to the past programme one could see naturally taking place in the former Vlněna complex [29]. In the Vlněna case, it was not about the historical value of individual objects (except for Bochner's Palace), but about the value of the whole complex itself as a witness of the crucial stage of the city's development. The replacement of the complex with administrative buildings which could fit anywhere is the most disturbing fact and a wasted opportunity for the City of Brno.

Without any long-term strategies, identification of qualities, potential, and discussions with developers and theinvolvement of each project participation, it is more than likely that it has been and will be very difficult to preserve any architectural, especially industrial heritage in the local context.

\section{References}

[1] ZEMÁNKOVÁ, Helena, 2003. Tvořit ve vytvořeném: nové funkční využívání uvolněných objektů. Brno: Vysoké učení technické v Brně, s. 41-71. ISBN 80-2142365-x.

[2] FRAGNER, Benjamin a Jan ZIKMUND, ed., c2009. Co jsme si zbořili: bilance mizející průmyslové éry - deset let $=$ What we destroyed (ourselves): taking stock of the vanishing industrial era - ten years. Praha: České vysoké učení technické. ISBN 978-80-01-04387-5.

[3] V areálu Zbrojovky se začalo bourat. Staré domy nahradí kanceláře, byty a obchody, 2017. In: Česká televize - ČT 24 [online]. Brno: Česká televize, 2. 11. 2017 [cit. 2018-05-29]. Available at: http://www.ceskatelevize.cz/ct24/ regiony/2292259-v-arealu-zbrojovky-se-zacalo-bourat-stare-domy-nahradikancelare-byty-a-obchody.

[4] STEINBACHOVÁ, Marcela, 2015. Exkurze Švýcarsko / Switzerland Excursion. CARUSO, Adam, Andrea DEPLAZES, Tom EMERSON et al. Kruh: texty o architektuře 2014-2015: švýcarsko-české inspirace. Praha: Kruh, s. 194-197. ISBN 978-80-903218-6-1. 
[5] VYSKOČIL, Aleš, 2017. Textile industry in Brno: A case study of cultural heritage and the memory of an industrial center (Kulturní dědictví a pamět industriálního centra (př́ípad textilního Brna)). Muzeológia a kultúrne dedičstvo [online]. Bratislava: Comenius University in Bratislava, 5(1), 84 [cit. 2018-05-20]. ISSN 1339-2204. Available at: https://doaj.org/article/4eff55585a2a4331af1b0b80a3ad a15d.

[6] Charta průmyslového dědictví TICCIH, c2013. In Praha: České vysoké učení technické, Výzkumné centrum průmyslového dědictví Fakulty architektury. ISBN 978-80-01-05235-8.

[7] Budoucnost centra Brna - 2 varianty, 2018. Brno - oficiální web statutárního města Brna [online]. Brno: Magistrát města Brna [cit. 2018-05-30]. Available at: https://www.brno.cz/sprava-mesta/magistrat-mesta-brna/usek-rozvoje-mesta/ odbor-uzemniho-planovani-a-rozvoje/dokumenty/budoucnost-centra-brna2-varianty/.

[8] VYSKOČIL, Aleš, 2017. Textile industry in Brno: A case study of cultural heritage and the memory of an industrial center (KULTURNÍ DĚDICTVÍ A PAMĚŤ INDUSTRIÁLNÍHO CENTRA (PŘÍPAD TEXTILNÍHO BRNA)). Muzeológia a Kultúrne Dedičstvo [online]. Comenius University in Bratislava, 5(1), 87 [cit. 2018-05-30]. ISSN 1339-2204. Available at: https://doaj.org/article/4eff55585a2a 4331af1b0b80a3ada15d.

[9] BŘEZINOVÁ, Andrea a Tomáš ZAPLETAL, ed., 2014. Brno - moravský Manchester. In Brno: Moravská galerie. ISBN 978-80-7027-277-0.

[10] GILBERTOVÁ, Marie, 2017. The industrial landscape of Brno as heritage and a platform for cultural and museum projects: The second life of the Brno brownfields and former eminent industrial objects (Průmyslová krajina města Brna jako významné dědictví a platforma pro kulturní a muzejní projekty. Druhá existence brněnských brownfieldů a bývalých slavných průmyslových objektů se zaměřením na textilní průmysl). Muzeológia a kultúrne dedičstvo [online]. Comenius University in Bratislava, 5(1), 100 [cit. 2018-05-30]. ISSN 1339-2204. Available at: https://doaj.org/article/58292f99d8fd4e3e8b7ce9e05e0bd7c7.

[11] Masarykova čtvrt' C001-C065. HLAVÁČKOVÁ, Petra, Rostislav KORYČÁNEK, Šárka SVOBODOVÁ a Lucie VALDHANSOVÁ, 2017. Brněnský architektonický manuál: průvodce architekturou 1918-1945. Druhé vydání. Brno: Dům umění města Brna, s. 40 a 46. ISBN 978-80-7009-179-1.

[12] CHLUP, Zdeněk, 1969. VLNĚNA, n. p., - Přízová 3, Brno. Brno, významné centrum československého průmyslu. Brno: Útvar hlav. architekta města Brna, s. 275.

[13] ZEMÁNKOVÁ, Helena a Petr VILÉM, 2004. Vlněna - Př́zová. Databáze průmyslového dědictví Moravy [online]. Brno: Vysoké učení technické v Brně. Fakulta architektury [cit. 2018-05-31]. Available at: https://www.fa.vutbr.cz/ 
home/zemankova/textil/01.htm.

[14] Vlněna: Life in factory [documentary]. Directed by Cosmi TCACIUC, Petr HÁJEK. Czech, 2014. Available at: https://youtu.be/P_R5xVqzGNQ.

[15] MAŠKA, Petr a Matyáš DLAB, 2011. Die_Sein. D’Epog [online]. Brno: D’EPOG [cit. 2018-05-31]. Available at: https://www.depog.com/cz/projekty/di-sein/.

[16] Centrum C066-C123. HLAVÁČKOVÁ, Petra, Rostislav KORYČÁNEK, Šárka SVOBODOVÁ a Lucie VALDHANSOVÁ, 2017. Brněnský architektonický manuál: průvodce architekturou 1918-1945. Druhé, doplněné vydání. Brno: Dům umění města Brna, s. 95. ISBN 978-80-7009-179-1.

[17] Commercial Real Estate Developer and Manager | CTP: premium industrial warehouse and office buildings [online], 2018. Humpolec: CTP INVEST [cit. 2018-05-31]. Available at: https://www.ctp.eu.

[18] KREJSOVÁ, Vladimíra, 2013. Bývalá brněnská textilka Vlněna půjde k zemi. Místo ní vznikne nové centrum. In: Deník.cz [online]. Brno: VLTAVA LABE MEDIA [cit. 2018-06-11]. Available at: https://www.denik.cz/ekonomika/vlnenainvestor-zdemoluje-50-budov-postavi-12-novych-20130906-ciah.html.

[19] Studio acht: designing for 40 years [online]. Praha: Studio acht, 2018 [cit. 201805-31]. Available at: http://www.studioacht.cz/.

[20] HOMOLA, Aleš, 2013. Vlněna - historie zániku architektonického a industriálního monumentu průmyslového věku. ZPRÁVY PAMÁTKOVÉ PÉČE: Časopis státní památkové péče. Praha: Národní památkový ústav, generální ředitelství, 73(3), 264-265. ISSN 1210-5538.

[21] SCHOELLHORN, Fritz, 1922. Das Braugewerbe und die Brauereien des Kantons Zürich. Winterthur: Buchdr. Winterthur.

[22] PSP Swiss Property [online]. Zug: PSP Swiss Property, 2018 [cit. 2018-06-05]. Available at: https://www.psp.info.

[23] GIGON, Anette a Mike GUYER, 2012. Gigon/Guyer Architects: Works \& Projects 2001-2011. Zürich: Lars Müller, s. 288-301. ISBN 9783037782767.

[24] KONZEPTIONELLER STÄDTEBAU (CONCEPTUAL URBANISM). Zürich baut: konzeptioneller Städtebau = Building Zurich: conceptual urbanism, 2007. Basel: Birkhäuser, s. 81-146. ISBN 9783764379964.

[25] BRNO BROWNFIELDS 2015. Brno, 2015. Available at: https://www.brno.cz/fileadmin/user_upload/Podnikatel/Brownfields/mmb_brownfields_EN_2015.pdf.

[26] DÖRRY, Sabine, Marit ROSOL a Fee THISSEN, 2016. The significance of creative industry policy narratives for Zurich's transformation toward a post-industrial city. Cities. 2016(58), 137-142. doi:https://doi.org/10.1016/j.cities.2016.05.022. ISSN 0264-275.

[27] HAVEL, Radek, ed., 2018. Počet obyvatel v obcích - k 1. 1. 2018. In: Český statistický úřad [online]. Praha: Český statistický úřad, 30. 4. 2018 [cit. 2018-06-07]. Available at: https://www.czso.cz/csu/czso/pocet-obyvatel-v-obcich-see2a5tx8j. 
[28] STAT-TAB - interaktive Tabellen (BFS). Swiss Federal Statistical Office - STATTAB [online], 2017. Neuchâtel: Federal Statistical Office [cit. 2018-06-07]. Available at: https://www.pxweb.bfs.admin.ch/pxweb/de/?rxid=02bd9bce-a261-4ee8b241-c27e3eba41c1.

[29] KREATIVNÍ CENTRUM BRNO. Česká Komora Architektů [online]. Praha: ČESKÁ KOMORA ARCHITEKTŮ, 2018 [cit. 2018-05-31]. Available at: https:// www.cka.cz/cs/souteze/vysledky/kreativni-centrum-brno. 